\title{
Competitive intelligence in emerging economies: A comparative study between Brazil and South Africa
}

$N$ SEWDASS AND ASA DU TOIT ${ }^{2}$

\begin{abstract}
Competitive intelligence $(\mathrm{CI})$ has long been recognised as a strategic management tool that could enhance competitiveness. CI is expected to play an essential developmental role in emerging economies. The need to enhance companies' competitiveness has grown rapidly. CI is essential, and will increasingly be a challenge in the years to come, especially for emerging economies. This article will compare CI activities in South Africa with CI activities in Brazil. Companies in these two countries have faced increased environmental uncertainty and increasingly there is a need to compete. A questionnaire survey methodology was used where questionnaires were administered to CI experts in organisations in South Africa and Brazil. The findings of the study revealed that only a limited number of organisations in Brazil and South Africa recognise the importance of a CI unit. It was also interesting to note that the CI function is more mature in South Africa than in Brazil. As Brazil and South Africa become more integrated into the global economy, it stands to reason that the global economy will have more of an impact on the countries' economies. To this end it has become more crucial to monitor global events and trends and it is very important for both countries to develop a CI culture.
\end{abstract}

Keywords: competitive intelligence, competitiveness, emerging economies, global economy, competitors, knowledge economy

\section{Introduction}

It has been stated that "the economic success of a country depends on its capacity to apply activities that create a competitive advantage, its ability to create an environment of transformation and progress, and its capacity to innovate" (Canongia, 2006: 58).

Competitive intelligence $(\mathrm{CI})$ has "long been recognised as a strategic management tool that could enhance competitiveness" (Du Toit, 2003: 113). This perception of CI as a strategic

1. Department of Business Management, University of South Africa, P.O. Box 392, Pretoria, 0003, SOUTH AFRICA. E-mail: sewdan@unisa.ac.za

2. Department of Information Science, University of Pretoria, Private Bag X20, Hatfield, Pretoria, 0028, South Africa, E-mail: adeline.dutoit@up.ac.za

TD The Journal for Transdisciplinary Research in Southern Africa, 11(1) July 2015, pp. 113-132. 
tool is not exclusive to developed countries. $\mathrm{CI}$ is expected to play an essential developmental role in developing countries as well. The need to "enhance companies' and by extension, countries' competitiveness has grown rapidly. CI is essential, and will increasingly be a challenge in the years to come, especially for emerging economies" (Canongia, 2006: 58).

Articles on CI activities in South Africa (Sewdass \& Du Toit, 2014) and on CI activities in Brazil (Du Toit \& Sewdass, 2014) were already published. This article will focus on a comparison of CI activities in the two countries and how these activities can increase the competitiveness of the two countries. Organisations in these two countries have faced increased environmental uncertainty and increasingly there is a need to compete in the global economy and to monitor and understand their environment more accurately for survival and success. Little research (Dou, n.d.; Dou, Dou \& Manullang, 2005; Du Toit, 2003) has been done on the application of $\mathrm{CI}$ in emerging economies. $\mathrm{CI}$ is always influenced by country-specific environmental factors (Calof \& Skinner, 1999: 21) and a questionnaire survey was conducted to compare CI activities in the two countries.

The business environment is highly complex in South Africa because of factors such as the country's unique history, diversity, geography, political and institutional landscape. Organisations in South Africa "tend to be less dynamic and more resistant to change, compared to organisations in industrialised countries" (Sewdass \& Du Toit, 2014: 198). Although CI in South Africa is enjoying increased prominence, it is not on the same level as in developed economics such as Canada, Japan and the USA (Viviers \& Muller, 2004: 59) and because of this competitiveness CI became a contemporary issue in South Africa. Within a short period of time after the democratic elections in South Africa in April 1994, the international market opened up. "South Africa as a net exporter of strategic minerals and the 'gateway' to Africa has an internal environment ideally suited to the use of CI by companies to gain the competitive edge in a developing domestic economy and a challenging external environment" (Viviers \& Muller, 2004: 54). CI is therefore enjoying increased prominence in South Africa. The limited information found on CI activities in South Africa and the fact that the last national comprehensive review of CI activities in South Africa was conducted in 2002 led the authors to undertake this project. Since 2002 no survey of all the industries was conducted and many organisations established a CI function. Two universities now offer CI training and more CI professionals are entering the market (Sewdass \& Du Toit, 2014: 185). Because of this, CI practices became more sophisticated since 2002 and a new survey was necessary.

Substantial political changes in Brazil since 1990 have also led to greater information exchange and the Brazilian society has been evolving into a knowledge society dealing with political changes, globalisation, new technologies, hyper competition and new global competitors, such as China. The Brazilian government and Brazilian companies have realized competing in a global economy requires a strong vision of what exists outside the country's borders. As a result, "CI is becoming more accepted both as a profession and as an important business function" (Libis, 2005: 238). In spite of this, the state of CI in South Africa and Brazil remains fragmented for decision makers who need reliable information to deploy innovative policies for economic development. 
Quite recently, South Africa has become a reference point for some Brazilian researchers. The recently formed group of Heads of State (or government) of India, Brazil, and South Africa (IBSA) meets annually and has formed the IBSA trilateral development initiative. The identity of this seemingly disparate group is that its members are unique in that they share large populations and areas, are developing countries, and have democratic governments. Cooperation has rapidly resulted in the signing of protocols to stimulate scientific research and in Brazil specific research funds are becoming available (Dwyer, 2009: 41). Over recent years, there has been much talk about the future world role to be played by a small group of previously subaltern or marginalised countries. These countries have large territories and populations and considerable natural resources and they constitute not only large markets but will be important producer nations. Most frequently referred to as the BRICS (Brazil, Russia, India, China and South Africa) this loose and highly diverse group of countries play an increasing role on the world stage in cultural, economic, and political terms (Dwyer, 2009: 41).

Competitiveness has increased in the knowledge economy. The domain of CI is broad with a synergy between the concepts CI, knowledge management, competitiveness, economics, information and technological foresight (Canongia, 2006: 58). Each concept is an established paradigm and has specific contextual meaning and a proper discussion of these concepts is beyond the scope of this article. CI prepares organisations for the future by way of a systematic knowledge management process (Calof \& Skinner, 1999: 20). It creates knowledge from openly available information by use of a systematic process of planning, collection, analysis and communication that result in decision-making. "CI delineates between information and its analysis to produce intelligence” (Prescott, 1999: 43).

Gabriel \& Adiele (2012: 27) report that CI can be approached from many angles such as information theory, military theory, experiential approach, problem solving in organisational theory and decision making. It is further noted that CI is also studied and used in marketing management, market intelligence, knowledge management, business management and strategic management. Although CI is reported to have evolved out of marketing research, it has developed its own methods and tools that can be applied to the above disciplines as well as other business functions in organisation. According to Walle (1999: 522) "CI has borrowed tools and techniques from the art of espionage" to provide relevant quality information to assist decision makers in businesses to see the holistic view of the business environment that they operate in.

The field has been spurred by the computer revolution, the wealth of data available via the Internet, and the need for techniques that have been specifically designed around the current situation. Other technological developments, such as the availability of satellite photographs, make it possible for CI professionals to study a wealth of empirical data which until recently was completely unavailable (Walle, 1999: 521).

According to Easton (2015), "transdisciplinarity can be regarded as a way of thinking and doing" Furthermore, the author indicates that in transdisciplinary research, the researchers have the freedom to follow a problem across disciplinary boundaries. They also need to be open to collaboration and innovation and to draw on concepts and methods of other disciplines and use these to create new approaches to problems and new ways of thinking and solving current problems in society. Some important properties of transdisciplinarity as identified by Kroeze \& Van Zyl (2014: 4 \& 8) include its "broad evolutionary scope, its focus on complex practical problems in society and attempts to find better solutions to these

Td 11(1), July 2015, pp. 113-132. 
problems, its holistic approach to deal with knowledge from various disciplines; its goal of finding practical solutions to problems and to change the behaviour of individuals significantly".

The field of $\mathrm{CI}$ and the $\mathrm{CI}$ process in particular ties in very well with the properties of transdisciplinarity outlined above. The CI process is holistic in nature in that it makes use of human intelligence techniques, various communication techniques as well as modern technology to collect data from the internal and the external environments in which the organisations operates in. Data is collected broadly from customers, stakeholders, competitors and various markets. In order to make sense of this data, different analysis methods (borrowed from other disciplines) are used and the information is then delivered to decision makers who apply practical solutions to the problems that they experience and this also involves a change in the way things are done in the organisation (processes) as well as a change in the behaviour of the individuals.

This study proceeds from a transdisciplinary, exploratory perspective as it attempts to provide a comparison of the implementation of CI in two emerging economies, namely, Brazil and South Africa. Data for this study is collected from various industries and with collaboration from experts from these industries as well as from the "Institute of Energy" in Brazil. This will provide various perspectives and insights on the topic in order to obtain a better understanding and to compare the implementation of CI practices in these industries as well as the respective countries.

\section{Objectives of the study}

Despite the economic potential of the South African and Brazilian economies, no research has been conducted comparing CI activities in these countries. The objectives of this article are: to determine the state of CI in South Africa and Brazil, to determine whether a relationship exists between $\mathrm{CI}$ and measures of business performance in these countries and to determine how these countries can use CI to improve competitiveness. Furthermore, insight on the level of importance attached to CI in South Africa and Brazil will be discussed. An understanding of the relationship between the size of the organisations and CI practices in these countries will also be established. The study will also attempt to provide examples of how these countries use CI to increase their competitiveness in the global economy.

Findings could interest academics and companies in emerging economies who ponder the need and importance of CI in strategic management. CI is an integral part of overall economic health in developed economies (Calof \& Skinner, 1999: 22), and this study could ultimately improve CI activities in emerging economies. The last national survey to determine the implementation of CI in South African organisations was conducted in 2002 by Viviers, Saayman, Calof and Muller. Since then Du Toit (2003) conducted a survey of CI implementation in the manufacturing industry. De Pelsmacker, Muller, Viviers, Saayman, Cuyvers and Jegers (2005) conducted a survey of exporting companies and Fatti (2013) conducted a survey of CI implementation in the pharmaceutical industry. Various surveys were also conducted in specific organisations but as mentioned, the last national survey was conducted in 2002. The last national survey in Brazil was in 2008 by Decaup and Domingues (2009) but most of the findings also concur with the study conducted by Libis (2005). Therefore this study is relevant and timely for both South Africa and Brazil. 


\section{Competitiveness in the global economy}

Competitiveness is a multifaceted concept and according to Garelli (2003: 702) the competitiveness of nations "focuses on the policies implemented by nations to shape the environment around enterprises" and economic value is only created within the context of an enterprise. According to Waheeduzzaman (2002: 13) the ultimate goal of competitiveness is to improve the standard of living or real income of the citizens of a country. Since companies actually compete in the global economy, many authors are of the opinion that when studying competitiveness, the focus should be on companies since they are the main engines of a country's competitiveness (Garelli, 2003: 704). Organisations like the World Economic Forum (WEF) and International Institute of Management Development (IMD) rate countries annually on the basis of various competitiveness indicators. The WEF publishes the Global Competitiveness Report annually and the IMD the World Competitiveness Yearbook. According to the WEF the eight factors that determine the competitiveness of a nation are openness, government, finance, infrastructure, technology, management, labour and institutions (Waheeduzzaman, 2002: 15). The IMD groups criteria into eight competitiveness input factors, namely domestic economy, international, government, finance, infrastructure, management, science and technology and people (Waheeduzzaman, 2002: 15).

A country's environment supports or threatens economic growth through its policies. A country like Brazil manages its competitive environment by relying on assets (land, people and natural resources) but is not necessarily competitive (Garelli, 2003: 706). The WEF Global IT Report notes that "although Brazil exhibits relatively high levels of ICT usage, with about half of its population using the Internet, a well-developed e-commerce industry (30th), and a government committed to offering a significant number of its services online; a poor business and innovation environment (135th), coupled with weaknesses in its educational system (121st) - notably in the area of mathematics and science (136th) hampers the full attainment of the economic impacts that ICTs can provide (64th)" (BillaoOsorio, Dutta \& Larvin, 2014: 27)

Technology has an impact on the competitiveness of nations and South Africa is leapfrogging technological infrastructures by focusing on mobile rather than fixed phones (Garelli, 2003: 708). "Access to mobile services continues to grow, and the prices of all communication services remain high by both African and global standards" (Eldis, 2014). The WEF Global IT Report (Billao-Osorio, Dutta \& Larvin, 2014: 20) indicates that South Africa is improving in using ICTs, and the business community seems to have taken the lead, using ICTs vigorously in interactions with other businesses.

Furthermore, as "a country becomes more competitive, the standard of living or per capita income increases and this helps the reduction of inequality within the country" (Waheeduzzaman, 2002: 16).

\section{Competitive intelligence}

With the increased volatility of the business environment, "countries and companies rely on early detection of environmental changes so that they may respond with appropriate counter measures" (Kahaner, 1996: 23). Since they require time to adapt to the changing environment they should have the ability to anticipate changes and imagine the consequences of alternative responses to those changes. They use CI to facilitate the identification of potential 
opportunities and threats. Because CI improves decision-making, it helps a company to meet or exceed its objectives and business goals (Hitt, Ireland \& Hoskisson, 2000: 208).

As companies compete in the global economy, the need for CI in a global context becomes essential for further success. Companies in emerging economies who are familiar with CI practices in their local regional markets may find the requirement to extend CI practices globally very difficult to accomplish in a structured way (James, 2000: 44).

The basis for $\mathrm{CI}$ is knowing the difference between information and intelligence. Executives usually have to read through several reports and proposals before making decisions, and it is often found that they are overwhelmed with information and lack intelligence that will enable them to make more efficient decisions. Therefore, "it can be said that the companies that are able to turn information into intelligence will succeed" (Sewdass, 2012: 24).

There are many definitions of CI. These definitions deal with the management of information to enable a country or an institution to take better decisions and to understand the relationships between partners, competitors, laws, regulations and social behaviour, which interact with their environment (Dou, Dou \& Manullang, 2005). CI is the process of developing actionable foresight regarding competitive dynamics and non-market factors that can be used to enhance competitive advantage (Calof \& Skinner, 1999: 20). CI is concerned with the techniques used to select and filter information from a variety of sources, to interpret and analyse it, to communicate it to the right people and to use it effectively (Calof \& Skinner, 1999: 21). Competitive dynamics refers to the evolution of an organisation's industry and the moves and countermoves of competitors, suppliers, customers, alliance partners and potential competitors (Prescott, 1999: 42; Waheeduzzaman, 2002: 14). Nonmarket factors such as government regulation, tariffs and the culture of a country impact competitive dynamics but are not suppliers of products or services to the industry (Prescot, 1999: 42-43). CI uses legally and ethically available public sources to assess the strengths and weaknesses of its competitors.

Globally, the terms 'business intelligence', 'competitor intelligence', 'market research', 'market monitoring', 'market intelligence', 'corporate intelligence', 'competitive information', 'commercial intelligence' and 'knowledge management' are used by organisations (Global Intelligence Agency, 2005: 7; McGonagle \& Vella, 2002: 35). However, for the purpose of this study, CI has been chosen as it best describes the activities that the study intends to discuss.

\section{$\mathrm{CI}$ in emerging economies}

Kahaner (1996: 25) states that CI has become the 'latest weapon in the world war of economics', in which many emerging economies view $\mathrm{CI}$ as a way to win economic wars against larger, more industrialised countries. By using their wits instead of weapons, these countries are able to turn raw information into usable intelligence to further their economic status. According to Calof and Skinner (1999: 20) a country will under-perform without an appropriate CI infrastructure and they quote Prescott and Gibbons by stating that "the key question is not whether governments should play a role in a company's CI efforts but what should be the purposes and methods used by government." Countries such as France, Sweden, Japan and Canada have recognised the value of government and industry working jointly in the development of an intelligence culture (Calof \& Skinner, 1999: 22). 
Kahaner (1996: 28-31) sights the following reasons as why companies need CI in the global economy:

- The pace of business is increasing rapidly. Businesses are required to handle more projects and make more decisions with more speed than before.

- Information overload. Technological development has developed the speed and availability of communication and information.

- Increased global competition from new customers. Increased access to resources increased the number of competitors and decreased the importance of close physical proximity.

- Existing competition is becoming more aggressive. Many market places are maturing resulting in companies increasing their market share at the expense of their competitors.

- Political changes affect companies quickly and forcefully. Many countries have moved from communism or socialism to capitalism in the last decades.

- Rapid technological change. The last decades have seen the introduction of wireless communication, personal computers, the Internet and biotechnology.

Apart from these reasons, Hawkins (2004: 51) emphasises that companies in emerging economies should use formal processes of collecting, analysing and disseminating intelligence to successfully compete in the global economy. CI management is a well-established function in industrialised countries, because managers realise that if they do not monitor the actions and activities of their competitors, their strategic plans will fail. However, managers in emerging economies continue to be surprised by undesirable changes in the environment and it appears that the advances in managing intelligence are as yet largely unknown in these economies.

Apart from the above reasons why organisations need CI, various benefits can be identified. $\mathrm{CI}$ can do more than just providing the organisation with intelligence for decision-making purposes. "A well-designed CI system can assist the organisation in their strategic planning process as well as in determining the intention and capabilities of its competitors, so that the extent of the risk to which the organisation is exposed, can be established"(Sewdass, 2009: 30). Furthermore, CI implementation within an organisation can serve as a catalyst in the decision-making process by converting data elements into actionable information that can be used in strategic decisions.

$\mathrm{CI}$ also has the ability to fill a primarily strategic role in the companies, with top managers being the most important users of CI information products. CI is also used in strategic planning and business development; continuous monitoring of the companies; and gathering of information on competitors, customers, and industries (Global Intelligence Alliance, 2005: 18).

It has further been noted that "the new paradigm in development economics is based on selfanalysis, self-reliance and self-renewal, which would seem to necessitate a developmentorientated intelligence policy in a country" (Du Toit, 2003: 112). Currently most emerging economies are weakly integrated with the global economy. For organisations to compete globally they are facing many challenges since consumers use the Internet to compare products and prices and they need to stay ahead of their competitors (Sewlal, 2004). If this situation is to change, major infrastructural investment in information systems and services, as well as technical training, is required (Sewdass, 2012: 12). Utilising CI will enable 
organisations in emerging economies to gain a greater market share and to compete successfully against international competitors (Pellissier \& Kruger, 2011).

The relationship between knowledge/education and competitiveness is well established in the literature and the role of $\mathrm{CI}$ is to create knowledge. Knowledge enhances the competitive base of emerging economies while competitiveness creates an environment where knowledge can be created and grow (Waheeduzzaman, 2002: 17). A skilled work force is key in providing companies with a competitive edge and there is a need in emerging economies to equip employees with the necessary knowledge and skills to enable them to adapt to accelerating technical and market changes (Hosseini, 2006: 79).

Ifan et al. (2004: 995) state that "after a period of recession and inflation, most developing countries have to face the necessity of improving their capacities to innovate and increase the competitiveness of their industries". Furthermore, in emerging economies, the creation of new products from their natural resources is important as it has the ability to contribute to the country's foreign direct investment (FDI) (Dou, Dou \& Manullang, 2005). In order to achieve this, the implementation of CI will be the answer.

\section{South African situation with regard to competitiveness}

South Africa faces new socio-economic challenges and research capacity needs to be developed in the context of the global economy. Before 1994 South Africa was isolated from the rest of the world "as a result of the apartheid regime and this inhibited competitiveness" (Viviers \& Muller, 2004: 54). The authors also state that "the use of CI before 1994 has mostly negative connotations since South African intelligence activities were mostly pursued by state institutions that were not trusted. Information about scientific and technological innovations developed in South Africa was disseminated through academic and technological journals, conferences and trade shows" (Viviers \& Muller, 2004: 55).

After 1994 the economy became more open and, along with export markets, domestic markets became increasingly larger and more competitive with increased globalisation of markets. Many industries were deregulated and privatised and there was a large construction boom due to the 2010 Soccer World Cup (Strauss, 2008: 15). To survive many South African companies needed to extensively globalise their business activities to exploit country differences and worldwide markets. This prompted companies to become more sensitive to external environments which includes monitoring political/legal, economic, technological, socio-cultural and industry forces such as competitors, customers and suppliers (Strauss \& Du Toit, 2010: 304).

According to the Global Competitiveness Report (Schwab, 2013: 42) sub-Saharan Africa has continued its growth rate by 5 percent in 2012 and it is expected to continue to grow similarly for the next two years thereby providing a silver lining in the rather uncertain global economy. The Global Competitive report of 2013/2014 (Schwab, 2013: 346) further indicates that South Africa had an overall ranking of $53^{\text {rd }}$ out of 148 countries. South Africa also ranked second among the BRICS countries.

By regional standards, South Africa benefits from the size of its economy and it ranked $25^{\text {th }}$ in the market size. The country's financial market development is ranked $3^{\text {rd }}$ and this indicates that there is a very high level of confidence and trust in South Africa's financial markets in other parts of the world. The Global Competitive report of 2013/2014 (Schwab, 
2013: 346) also indicates that South Africa does reasonably well in areas such as business sophistication $\left(35^{\text {th }}\right)$ and innovation $\left(39^{\text {th }}\right)$. These are a few examples that indicate that South Africa is the most competitive economy in the region as compared to other African counterparts such as Zimbabwe $\left(131^{\text {st }}\right)$, Kenya $\left(96^{\text {th }}\right)$, Mozambique $\left(137^{\text {th }}\right)$, Nigeria $\left(120^{\text {th }}\right)$ and Ghana $\left(114^{\text {th }}\right)$ (Schwab, 2013). In order to further enhance its competitiveness, South Africa will need to address the most problematic factors for doing business.

Inefficient government bureaucracy, inadequately educated workforce, restrictive labour regulations and corruption in South Africa are the most critical areas that pose problems for other countries doing business with South Africa (Schwab, 2013: 346). South Africa contributed $46.5 \%$ of the total ICT services market in Africa in 2012 (Bakker, 2013).

According to the Global Competitiveness Index 2013-2014 (2013: 43), "South Africa is ranked $53^{\text {rd }}$ this year, overtaking Brazil to place second among the BRICS. South Africa does well on measures of the quality of its institutions $\left(41^{\text {st }}\right)$, including intellectual property protection $\left(18^{\text {th }}\right)$, property rights $\left(20^{\text {th }}\right)$, and in the efficiency of the legal framework in challenging and settling disputes $\left(13^{\text {th }}\right.$ and $12^{\text {th }}$, respectively)."

\section{Brazilian situation with regard to competitiveness}

CI was introduced in Brazil in the mid-1990s as an initiative of the National Institute of Technology. A CI interest group, the Competitive Intelligence Society of Brazil (ABRAIC) was established and is sponsored by the government and industry. The growing market for CI created the development of consulting activities. Various CI tools were developed (for example a national database of science competencies) (Dou, n.d.: 29).

According to the Global Competitiveness Report 2013-2014 (Schwab, 2013: 134), Brazil is ranked $56^{\text {th }}$ out of 148 countries. Brazil has also benefited from several competitive strengths. These strengths include its internal market size $\left(9^{\text {th }}\right)$, a sophisticated business environment $\left(39^{\text {th }}\right)$ and innovation $\left(55^{\text {th }}\right)$. The country also has an efficient financial market that is ranked $50^{\text {th }}$ and the rate of technology adoption is relatively high at $55^{\text {th }}$ compared to other countries in its region. However, there are several problematic areas that hinder countries from doing business with Brazil. Factors such as tax rates, tax regulations, inadequate supply of infrastructure, inefficient government bureaucracy and restrictive labour regulations, rank high as problem areas for doing business in Brazil and these factors also have an impact on Brazil's capacity to fulfil and sustain its competitive potential.

\section{Summary of CI in South Africa and Brazil}

Table 1 (below) provides a summary of CI implementation in Brazil and South Africa and it should be noted that this data is based on the study conducted by Libis (2005: 237-251) in Brazil and Viviers et al. (2002: 27-37) in South Africa. 
Table 1. Competitive intelligence: Brazil versus South Africa

\begin{tabular}{|c|c|c|}
\hline & Brazil & South Africa \\
\hline Acceptance of CI & $\begin{array}{l}\text { Limited, CI is not widely accepted in business. } \\
\text { Brazil's decision makers do not seem to } \\
\text { motivate for establishing CI capabilities in } \\
\text { their companies. } \\
\text { However, they do have CI departments in } \\
\text { international companies based in Brazil }\end{array}$ & $\begin{array}{l}\text { Lack of appropriate progress or structures for } \\
\text { CI in organisations. } \\
\text { Poor in formal organisation and process for CI } \\
\text { in organisations. Few companies have a central } \\
\text { coordinating point for CI. } \\
\text { CI does exist in international companies } \\
\text { operating in South Africa, e.g. Toyota. }\end{array}$ \\
\hline Location of CI & $\begin{array}{l}\text { CI usually located in Marketing departments } \\
\text { where CI is limited to market research. Hence } \\
\text { most CI activities are tactical and focus on the } \\
\text { creation of front-line actionable intelligence } \\
\text { and remain far away from senior managers - } \\
\text { detached from decision makers. } \\
\text { Strategic location in larger companies only. }\end{array}$ & $\begin{array}{l}\text { CI mostly located in sales and marketing } \\
\text { divisions in organisations. Marketing managers } \\
\text { and CEOs take responsibility for CI. } \\
\text { Most CI products are used widely in larger } \\
\text { companies as they are in the position to afford } \\
\text { them. }\end{array}$ \\
\hline $\begin{array}{l}\text { Quality } \\
\text { secondary } \\
\text { sources }\end{array}$ & $\begin{array}{l}\text { Limited secondary resources, unreliable sources } \\
\text { and underdeveloped internet infrastructure. } \\
\text { Slow growth in online population and lack of } \\
\text { online content published in Portuguese. } \\
\text { Limited creation, dissemination and } \\
\text { maintenance of business information by } \\
\text { government and public business reporting in } \\
\text { Brazil is questionable hence business does not } \\
\text { government and undertake convoluted } \\
\text { measures to avoid tax levels, hence tainting the } \\
\text { quality and availability of secondary research. }\end{array}$ & $\begin{array}{l}\text { Market research that was done was corrupted } \\
\text { and the company's outlook and approach was } \\
\text { so antiquated that it failed to realize what the } \\
\text { market was doing and what competitors were } \\
\text { up to. } \\
\text { CI in SA emerged from the business sector and } \\
\text { academia was not initially involved in research } \\
\text { into CI. Hence, only a few papers were written } \\
\text { on the subject. }\end{array}$ \\
\hline $\begin{array}{l}\text { Quality of } \\
\text { primary sources }\end{array}$ & $\begin{array}{l}\text { Abundant access to primary research but } \\
\text { credibility of these resources is questionable. } \\
\text { Information is power in Brazil, so it is } \\
\text { protected and hoarded in most businesses and } \\
\text { social settings. } \\
\text { Third party referral is often used to share and } \\
\text { gain access to information. }\end{array}$ & $\begin{array}{l}\text { People inside organisations use primary sources } \\
\text { of information. } \\
\text { Little information sharing took place and } \\
\text { people did not know what the focus of } \\
\text { intelligence activities were. }\end{array}$ \\
\hline $\begin{array}{l}\text { Capacity } \\
\text { analysis }\end{array}$ & $\begin{array}{l}\text { Limited due to the lack of acceptance of CI } \\
\text { and limited primary and secondary resources. } \\
\text { CI practitioners stick to basic frameworks only } \\
\text { such as the SWOT, financial ration and } \\
\text { historical analysis tools in analysis and to win } \\
\text { support of decision makers in organisations. }\end{array}$ & $\begin{array}{l}\text { Most CI time is spent on collecting } \\
\text { information rather than planning and analysis. } \\
\text { Efficiency and expertise in more advanced } \\
\text { competitive analysis tools is lacking with most } \\
\text { analysis skills limited to basic techniques such } \\
\text { as SWOT, PEST, low level profiling of } \\
\text { competitors, markets and industries. }\end{array}$ \\
\hline $\begin{array}{l}\text { CI Education \& } \\
\text { Training }\end{array}$ & $\begin{array}{l}\text { Limited. Only two academic institutions in } \\
\text { Brazil offer CI education and are based on } \\
\text { theoretical frameworks. These are not useful in } \\
\text { the expanding business markets. } \\
\text { Two professional associations ABRIAC \& } \\
\text { SCIP promotes CI awareness programmes. }\end{array}$ & $\begin{array}{l}\text { Few formal academic programmes have been } \\
\text { developed that offer CI training to individuals. } \\
\text { Students are usually involved in business } \\
\text { analysis activities in large companies and } \\
\text { government departments. } \\
\text { Ad hoc training programmes presented by } \\
\text { local and international CI consultants and } \\
\text { practitioners are hosted by conferences. }\end{array}$ \\
\hline Ethics and law & $\begin{array}{l}\text { Limited. Ethical frameworks are not followed } \\
\text { due to lack of support from government and } \\
\text { lack of participation in industry associations. } \\
\text { CI regarded as spying. } \\
\text { Business law loopholes are commonly exploited } \\
\text { to reduce taxes, increase profitability and } \\
\text { maintain competitiveness. }\end{array}$ & $\begin{array}{l}\text { Most CI activities are outsourced to consulting } \\
\text { companies and consultants were involved in } \\
\text { counter-intelligence and perhaps less ethical } \\
\text { information gathering activities also dominated } \\
\text { CI in SA. } \\
\text { CI was associated with industrial espionage } \\
\text { due to the role that the security establishment } \\
\text { had in the apartheid days and the connotations } \\
\text { made between intelligence and spying. } \\
\text { Doubt from government for the legitimacy of } \\
\text { CI. }\end{array}$ \\
\hline
\end{tabular}




\section{Research methodology}

Since CI is a relatively new activity in emerging economies, this study is mainly exploratory in nature. It attempts to provide a comparison of the implementation of $\mathrm{CI}$ in two emerging economies, namely South Africa and Brazil.

A questionnaire survey methodology was used where questionnaires were administered to CI practitioners in organisations in South Africa and Brazil. The organisations surveyed for the study were based on the Standard Industrial Classification that is used worldwide and comprises of ten categories. An additional category, the oil and gas industry, was added specifically for the benefit of Brazil where these industries have flourished in recent years and they have become a major player in the Brazilian economy. Hence the industry classification used in the study was as follows:

- Agriculture, hunting, forestry and fishing industry

- Mining and quarrying industry

- Manufacturing industry

- Electricity, gas and water supply industry

- Construction industry

- Wholesale and retail trade industry

- Tourism industry

- Transport, storage and communication industry

- Financial, insurance, real estate and business services

- Community, social and personal services

- Oil and gas industry

A combination of convenience sampling and snowball sampling were used to identify the practitioners in $\mathrm{CI}$ in these industries. Convenience sampling refers to the procedure of obtaining respondents (units or people) who are most conveniently available (Zikmund, 1994: 367). Snowball sampling, on the other hand, refers to procedures in which additional respondents are obtained from information provided by initial respondents. This technique is used to locate members of rare populations by referrals (Cooper \& Schindler, 2007: 425). CI practices in South Africa and Brazil are still in the early phase of development and when CI is practiced by individuals in organisations, it is still a matter of sensitivity (Strauss \& Du Toit, 2010: 311; Decaup \& Domingues, 2009: 25). Furthermore, in South Africa there is no recognized list of practicing CI professionals available (Viviers \& Muller, 2004: 56) and in Brazil a similar situation exists where networking takes on an important role in the development of CI (Libis, 2005: 249). Thus the researchers had to rely on their personal contacts and networks in industries to identify the experts in CI. These experts were assumed to have a sound knowledge of CI, its implementation and benefits for organisations. This is perhaps a limitation of this study as some important experts practicing CI could possibly be left out of the survey.

The questionnaire was structured as follows:

- Section A: Background and demographic information

- Section B: Competitive situation in organisations

- Section C: Competitive intelligence implementation in organisations

In order to test the questionnaire, a preliminary test was electronically distributed to six CI professionals. The aim of the pilot study was to determine the ease of understanding and the 
time taken to complete the questionnaire and minor changes were made to the original questions. The questionnaire was then finalised and sent as an attachment via email and it was accompanied by a cover letter to all identified respondents. The completed questionnaires had to be returned to the email of the researchers. The questionnaire was also translated into Portuguese for the Brazilian respondents and the translation and data collection was facilitated by Prof Camilo Augusto Sequeira from the Institute of Energy at the Universidade Catolica in Rio de Janeiro. In South Africa the questionnaires were emailed to 40 companies and 24 questionnaires were completed which represents a response rate of 60\%. In Brazil questionnaires were emailed to 33 companies and 13 questionnaires were completed representing a response rate of $39.3 \%$.

The data in the questionnaires was analysed using quantitative (numerical) analysis methods. According to Walliman (2005: 302) quantitative research looks for patterns in what is observed and these patterns should be interpreted. The analytical approach followed in quantitative research requires descriptive statistics that describe numerical data. The questionnaire responses were processed using the Microsoft Excel tool to arrange the data in logical order and to analyse it. Descriptive statistics were then used to summarise the findings.

\section{Findings and analysis}

\section{Biographical data}

In South Africa the gender of the respondents was mostly male (70\%) while in Brazil the gender was almost equal (53.8\% male and $46.2 \%$ female). In Brazil $84.6 \%$ of the respondents were younger than 50 years while in South Africa $50 \%$ of the respondents were younger than 50 years. The majority of respondents in South Africa had postgraduate degrees and was either top management or senior/middle management level of their organisations' (85\%), while the majority of respondents in Brazil has bachelor's degrees and were either in top management or senior/middle management level of their organisation's (69.2\%). The South African findings here correlate with the findings of Du Toit and Strauss (2010: 312) which also found that majority of the individuals in their study had postgraduate qualifications and were situated in top management or senior/middle management levels in the organisations.

In Brazil the majority of the respondents (76.9\%) were employed by companies with more than 500 employees compared to South Africa where only 50\% of the respondents were employed by companies with more than 500 employees. It is interesting to note that in South Africa four companies with less than 50 companies also use CI as a strategic tool.

With regard to industries the majority of companies in Brazil were in the manufacturing industry (30.7\%) while in South Africa the majority of companies were in financial, insurance, real estate and business services (25\%).

\section{Competitive situation}

In South Africa 55\% of the organisations are of the opinion that they cope above average with changes in the business environment. This is an indication that organisations in SA should pay more attention to CI as a strategic business tool. In Brazil only $46.1 \%$ of the organisations indicated that they cope above average. This is an indication that a large percentage of CI practitioners in Brazil are probably not aware of the importance of scanning 
the environment as an early-warning tool to adapt strategies. The majority of South African organisations indicated that competition in their business environment is very intense $(65 \%)$ compared to the organisations in Brazil where only $23 \%$ of the organisations indicated that competition is very intense.

\section{Competitive intelligence function/unit}

According to the majority of respondents in South Africa (60\%), a formal CI function does exist in their organisation while in Brazil a formal CI function exists at only $15.4 \%$ of the organisations. In South Africa the CI function has been in existence for more than five years in $65 \%$ of the companies while in Brazil none of the companies had a CI function for more than five years. This indicates that the CI function is more mature in South Africa than in Brazil.

\section{CI activities}

With regard to the five most important $\mathrm{CI}$ activities implemented by organisations, $85 \%$ of the respondents in Brazil evaluate the reliability and accuracy of information while $61.5 \%$ of the respondents use CI to quantify/qualify strategic choices. The majority of respondents $(84.6 \%)$ agreed that their staff members report back on competitor actions and $54 \%$ of the respondents use $\mathrm{CI}$ to achieve strategic objectives and to be aware of strategic objectives (see Figure 1).

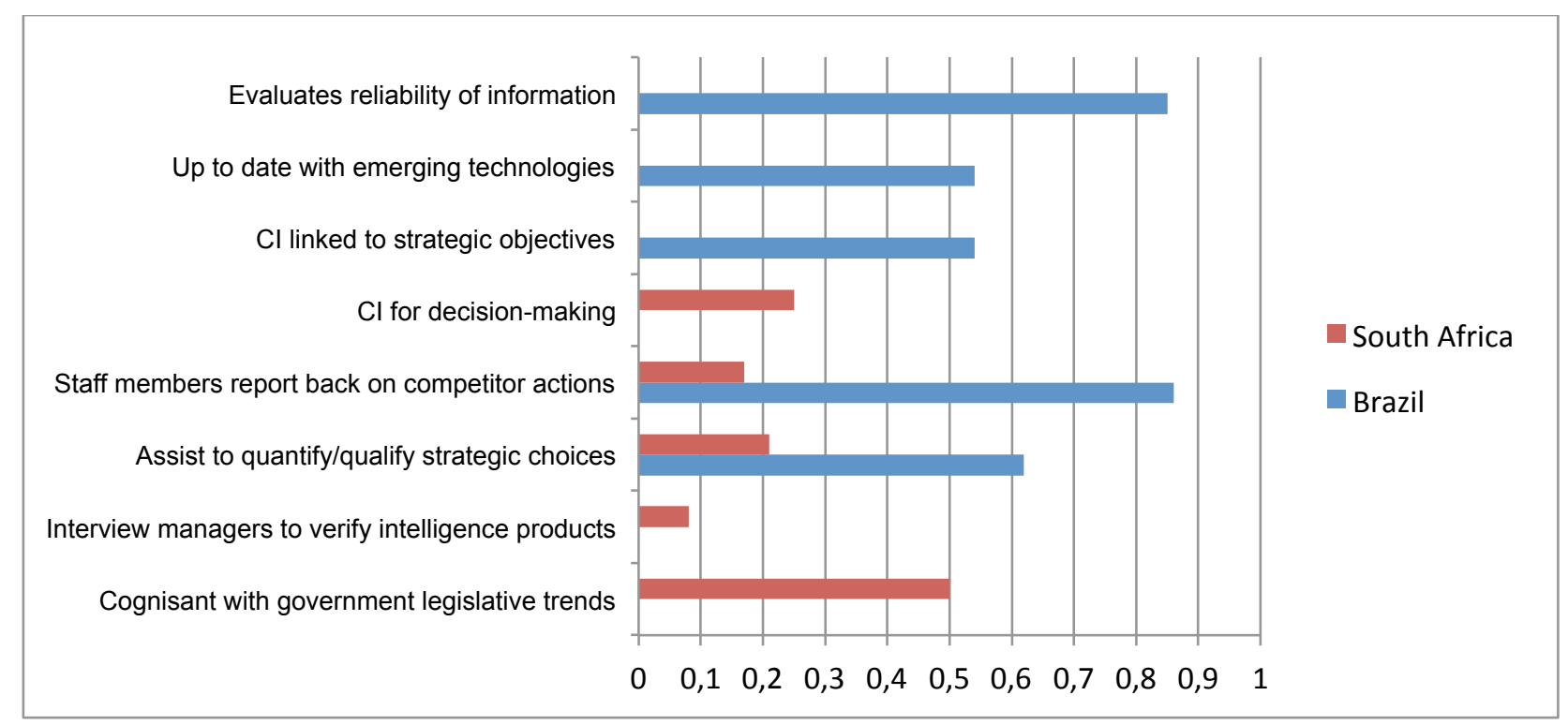

Figure 1: Five most important CI activities

With regard to the situation in South Africa, 25\% of the respondents use CI for decisionmaking while $50 \%$ of the respondents use $\mathrm{CI}$ to remain cognisant with government legislative trends. Twenty-one per cent of the respondents use CI to assist in the quantification/qualification of strategic choices while $17 \%$ of staff members report back on competitor actions. Eight per cent of respondents interview managers to verify intelligence products. This is also an indication of the maturity level of CI in South Africa (see Figure 1). 


\section{Use of secondary sources}

In Brazil, respondents identified promotional material, information on regulatory bodies and sales forecasts as the most important secondary sources used by them (see Figure 2). It is interesting that $31 \%$ of the respondents never use corporate annual reports or survey summaries $(38 \%)$.

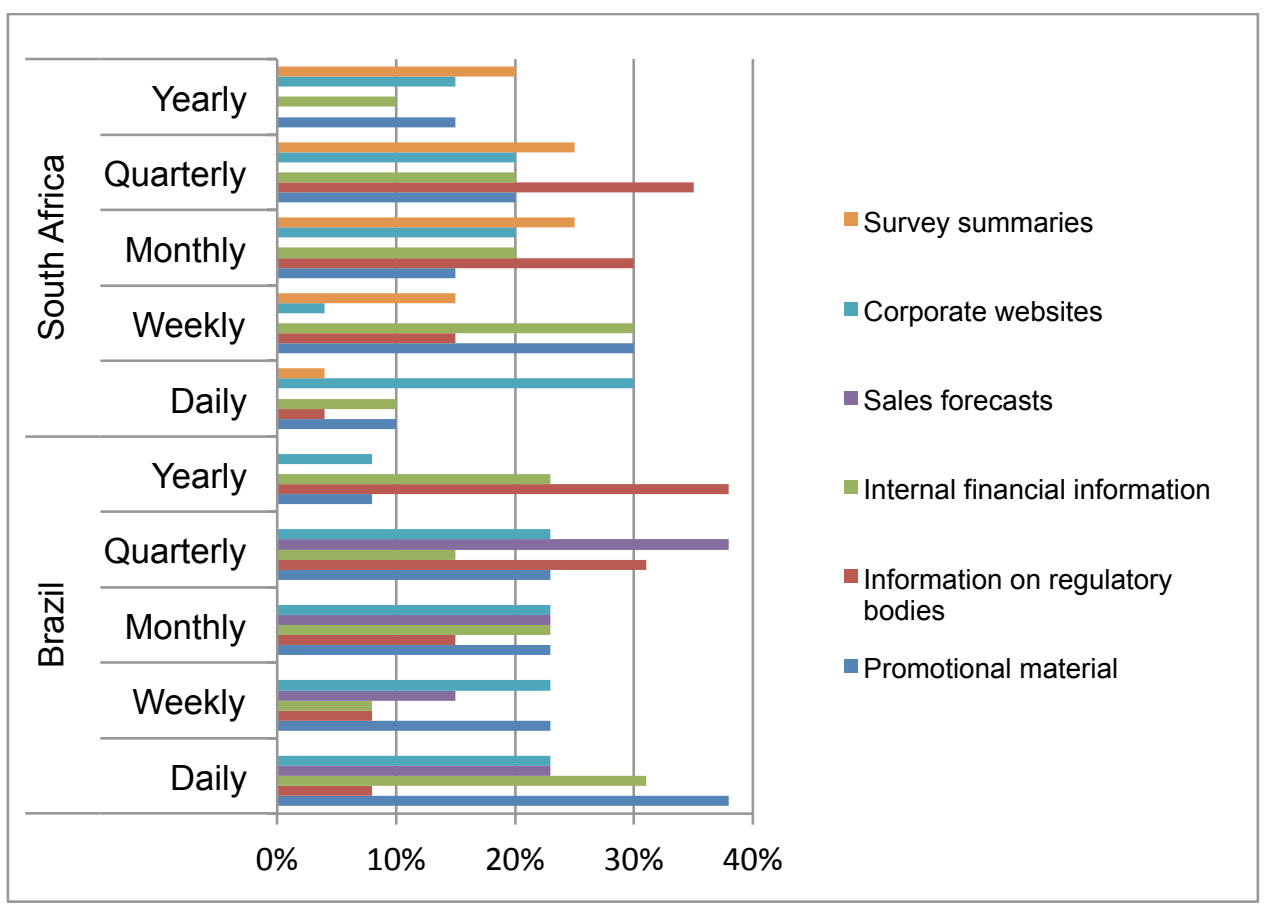

Figure 2: Use of secondary sources

The most important secondary source used by South African organisations is information on regulatory bodies (see Figure 2). The fact that information on regulatory bodies is so important, is an indication that restrictive regulations (enacted by the government) often contribute to a decline in competitiveness. This is in contrast with developed countries where deregulation enhances competitiveness. Promotional material, internal financial information and corporate websites are also important sources.

\section{Use of primary sources}

The most important primary sources used by organisations in Brazil are direct customer feedback; suppliers and analysis of competitor's feedback (see Figure 3). This finding correlates with the findings of Libis (2005: 241) that there is abundant access to primary research but that credibility of the sources is questionable. Organisations therefore prefer to collect their own information directly from customers. 


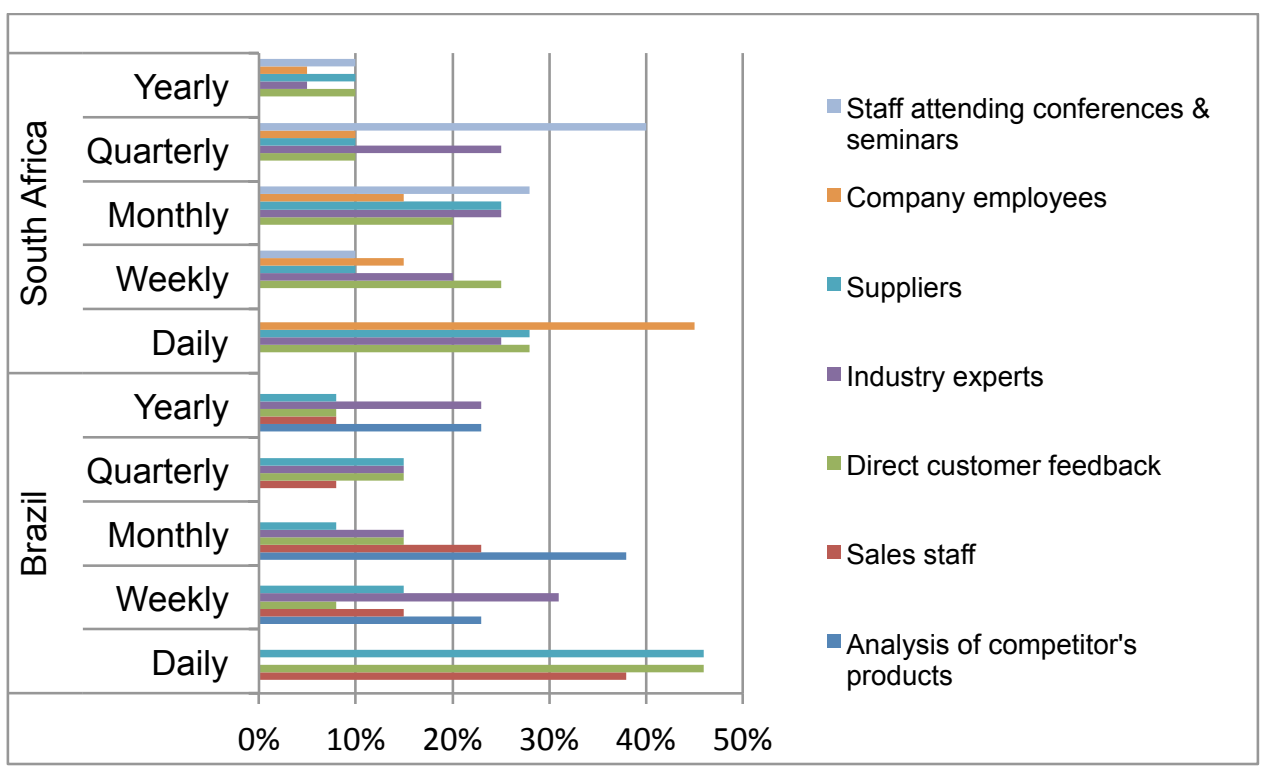

Figure 3: Use of primary sources

The most important primary sources used by organisations in South Africa are industry experts, direct customer feedback and company employees. Staff who attend conferences and seminars are also important information sources. This indicates that South African organisations sensitize and train their employees to collect information on the competitive environment (see Figure 3).

\section{Analytical methods or models used}

The majority of organisations in Brazil (61.5\%) used competitor analysis and $46.2 \%$ of them used SWOT analysis and Customer Segmentation Analysis while only 30.7\% of the organisations used Financial Ratio and Statement Analysis (see Figure 4). This indicates that organisations in Brazil do not use sophisticated analysis techniques.

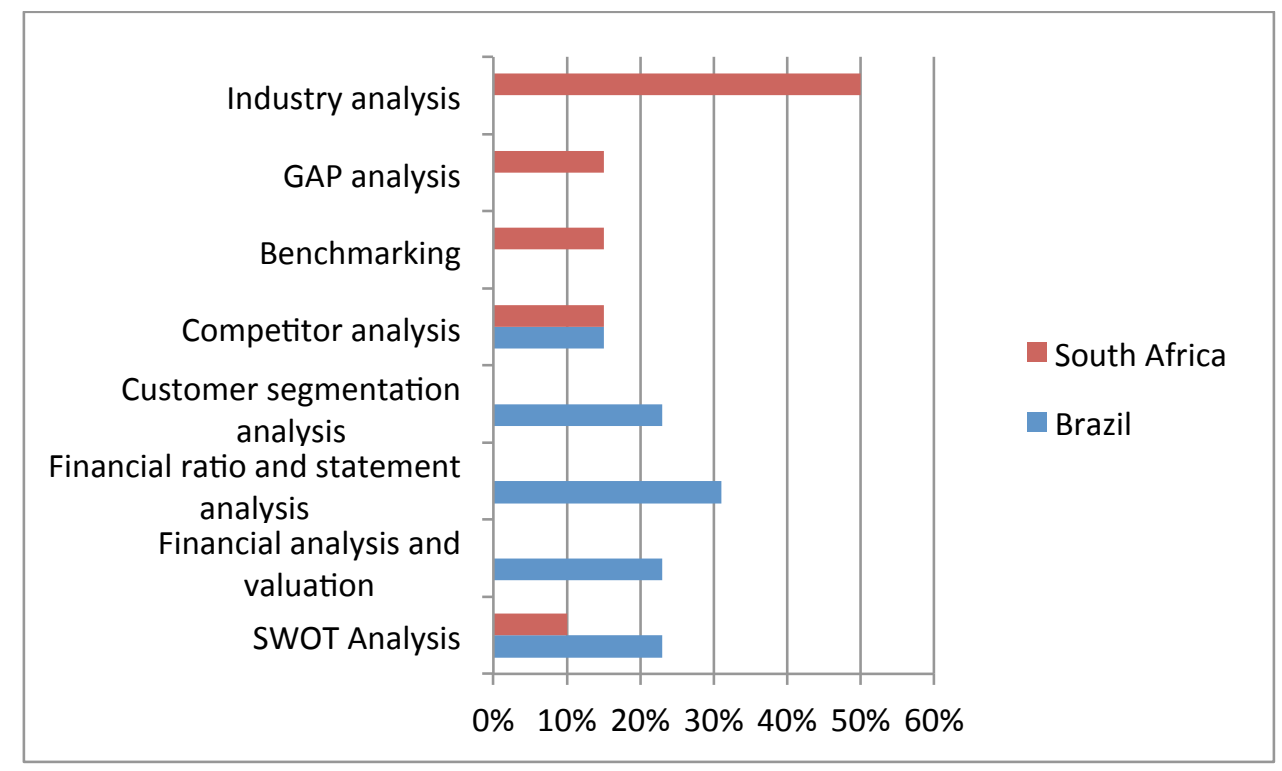

Figure 4: Analysis methods or models used

With regard to the use of CI analytical methods or models in South Africa, $50 \%$ of the respondents used industry analysis while $10 \%$ of the respondents used SWOT analysis (see 
Figure 4). Benchmarking, competitor analysis and GAP analysis are used by $15 \%$ of the organisations. This corroborates with the findings of Viviers and Muller (2004: 64) that South African organisations do not use sophisticated analysis techniques.

\section{Methods used to distribute and present CI findings}

The majority of respondents in Brazil (46.2\%) used email and customer/competitor/supplier profiles to distribute CI findings. Reports and market and industry audits are used by $38.5 \%$ of the respondents. Presentations are used by $30.8 \%$ of the respondents (see Figure 5).

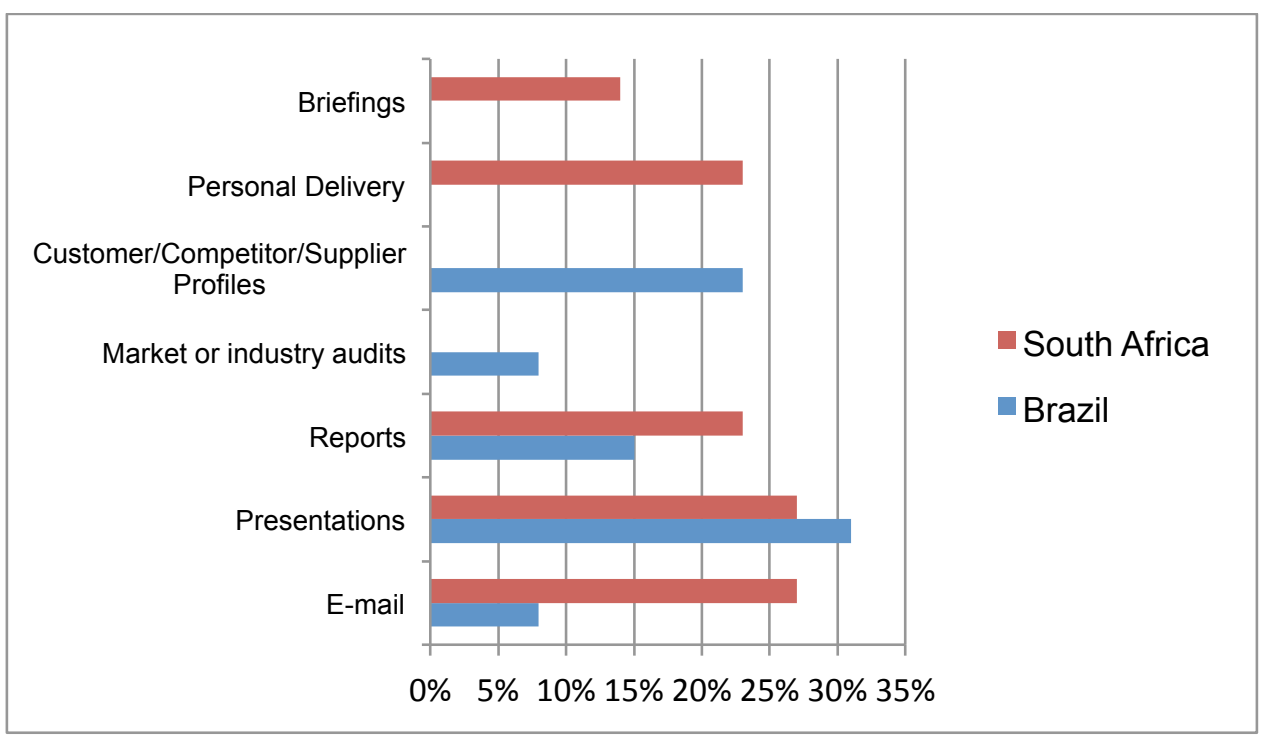

Figure 5: Methods used to distribute \& present CI findings

The most popular method to distribute CI findings in South Africa is presentations which are used by $27 \%$ of the respondents. Briefings are used by $14 \%$ of the respondents. This is also an indication that CI is practiced on a mature level in South Africa. Email is used by $27 \%$ of the respondents and personal delivery and reports by $23 \%$ of the respondents (see Figure 5).

\section{Recommendations and conclusions}

As Brazil and South Africa become more integrated into the global economy it stands to reason that the global economy will have more of an impact on the countries' economy. To this end it has become more crucial to monitor global events and trends and it is very important for both countries to develop a CI culture. CI analyses not just the environment but competitors and markets as well. Therefore, understanding the direction that competitors are moving to in the future is essential to be able to counteract them timeously. Keeping abreast of domestic and international market trends and their potential impact on organisations in both countries is vital. Trend tracking needs to monitor the impact of not only product changes but also organisational changes such as future mergers and dissolutions. It is also recommended that organisations in both countries should enhance a CI culture by creating CI awareness among employees and provide CI training sessions for new employees.

CI could enhance the competitiveness of South African organisations in the global economy. There is clear recognition that the world will become more competitive and will increasingly do so. Whether South African managers will meet these challenges is not clear and according 
to the empirical survey conducted, few have actual plans to improve their ability to keep track of competitors and to enhance their competitiveness. There appears to be a degree of complacency and self-deception that is inhibiting managers from instigating effective planning to improve $\mathrm{CI}$ and few conduct $\mathrm{CI}$ in a formal systematic manner. CI should assist senior management to develop and review a set of key intelligence needs (KINs).

Only a limited number of organisations in Brazil recognises the importance of a CI unit and did not indicate the use of CI for decision-making as one of the five most important CI activities. CI should assist senior management to develop and review a set of key intelligence needs (KINs). In order to provide direction to the CI function in these organisations, it is important that they should interview management on a regular basis. According to the survey organisations in Brazil do not use sophisticated techniques such as blind-spot analysis and scenario analysis to analyse CI data. The use of these techniques as early warning signals is very important to get a head-start on competitive organisations in the global economy. The CI function in organisations in Brazil should thus evolve from 'providing just the facts' (reactive) to being 'a key component of company strategy' (proactive).

It is recommended that organisations in Brazil should seek to engage proactively with the global environment by revising their strategic priorities. It is therefore evident that organisations in Brazil need to redress some critical competitiveness issues, most notably the establishment of the CI function as a strategic tool. Without a CI strategy, organisations will find it difficult to position themselves in the global marketplace.

A limitation of this research is that a small sample was used and further research which includes a larger sample will have to be conducted. In the light of the world-wide interest in $\mathrm{CI}$ in developing countries and the desire to understand how South Africa and Brazil can improve its competitiveness, the hope is expressed that the South African and Brazilian governments and industries will in future create an environment which will facilitate the competitiveness of organisations and encourage long-term sustainability.

\section{Acknowledgement}

The authors will like to acknowledge Prof C.A. Sequeira, Institute of Energy, Catholic University, Rio de Janeiro, Brazil for his assistance in the data collection in Brazil. The findings of this study were presented at the Global Business and Technology Association (GBATA) Fifteenth Annual International Conference held in Helsinki, Finland, July 2nd 6th, 2013.

\section{Bibliography}

Bakker, B. 2013. ICT growth in Africa. [Online]. Available: http://www.itweb.co.za/index.php?option=com_content\&view=article\&id=65664 [Accessed: 5 May 2014]

Billao-Osorio, B., Dutta, S. \& Larvin, B. (Eds). 2014. The global information technology report 2014: Rewards and risks of big data. World Economic Forum. [Online]. Available: http://www.weforum.org/reports/global-information-technology-report2014. [Accessed 17 September 2014] 
Calof, J. \& Skinner, B. 1999. Government's role in competitive intelligence: What's happening in Canada? Competitive Intelligence Magazine, 2(2): 20-23.

Canongia, C. 2006. Synergy between competitive intelligence (CI), knowledge management (KM) and technological foresight (TF) as a strategic model of prospecting - the use of biotechnology in the development of drugs against breast cancer. Biotechnology Advances, 25: 57-74.

Cooper, D.R. \& Schindler, P.S. 2007. Business research methods. $9^{\text {th }}$ ed. New York: McGrawHill.

Decaup, A. \& Domingues, F. 2009. Competitive intelligence practices implementation in Brazilian companies. Competitive Intelligence Magazine, 12(3): 20-25.

De Pelsmacker, P., Muller, M-L., Viviers, W., Saayman, A., Cuyvers, L. \& Jegers, M. 2005. Competitive intelligence practices of South African and Belgian exporters. Marketing Intelligence E Planning, 23(6): 606-620.

Dou, H. (n.d.). Competitive intelligence worldwide. [Online]. Available: http://www.ciworldwide.org. [Accessed 11 March, 2010]

Dou, H., Dou Jr., J.M., \& Manullang, S.D. 2005. The magic triangle - how to develop and apply competitive intelligence in developing countries. [Online]. Available: http://isdm.univ-tln.fr/PDF/isdm22/isdm22_dou.pdf. [Accessed 12 February 2009]

Du Toit, A.S.A. 2003. Competitive intelligence in the knowledge economy: What is in it for South African manufacturing enterprises? International Journal of Information Management, 23(1): 111-120.

Du Toit, A.S.A. \& Sewdass, N. 2014. Competitive intelligence practices in Brazil: An exploratory study. Mousaion, 32(1): 85-98.

Dwyer, T. 2009. On the internalization of Brazilian academic Sociology. ISA E-Bulletin, 13: 20-47.

Easton, P. 2015. Letters from the interim director. [Online]. Available: www.cgu.edu/transdisciplinary. [Accessed 20 February 2015].

Eldis. 2014. Understanding what is happening in ICT in South Africa: A supply- and demand-side analysis of the ICT sector. [Online]. Available: http://www.eldis.org/go/home\&id=66089\&type=Document\#.U2onqvldUW1 [Accessed: 15 April 2014]

Fatti, A.C. 2013. Competitive intelligence in the South African pharmaceutical industry. MPhil dissertation. Johannesburg: University of Johannesburg.

Gabriel, J.M.O. \& Adiele, K.C. 2012. Competitive Intelligence as Panacea for Environmental Vagaries in Nigeria. Economic Journal of A 2 Z, 1 (1): 25-30.

Garelli, S. 2003. Competitiveness of nations: The fundamentals. [Online]. Available: http://www.imd.org/uupload/www01/documents/wcc/content/fundamentals.pdf. [Accessed 20 February 2015].

Global Intelligence Alliance. 2005. Competitive Intelligence in large companies - global study. GIA White Paper 4/2005. [Online]. Available: http://www.globalintelligence.com. [Accessed 2 December 2005]. 
Hawkins, D.B. 2004. Competitive intelligence in New Zealand. Journal of Competitive Intelligence and Management, 2(4): 42-52.

Hitt, M., Ireland, R. \& Hoskisson, R. 2000. Case notes for strategic management: Competitiveness and globalization. Annotated Textbook, 4(1): 208.

Hosseini, N.D. 2006. Lifelong learning and the knowledge society: Challenges for developing countries. Journal of College Teaching E Learning, 3(12): 79-83.

Ifan, H-K., Dou, J-M., Manullang, S. \& Dou, H. 2004. Developing competitive technical intelligence in Indonesia. Technovation, 24: 995-999.

James, S. 2000. Focus on global competitive intelligence. Information Outlook, 4(2): 43-46.

Kahaner, L. 1996. Competitive intelligence: From black ops to boardrooms - how businesses gather, analyse, and use information to succeed in the global marketplace. New York: Simon \& Schuster.

Kroeze, J.H.A. \& Van Zyl, I. 2014. Transdisciplinarity in Information Systems: Extended reflections. Twentieth Americas Conference on Information Systems, Savannah.

Libis, J. 2005. Competitive intelligence in Brazil. In: Competitive intelligence and global business. Edited by D.L.Blenkhorn \& C.S. Fleisher. 2005. Westpoint, Connecticut: Praeger. Pp. 237-251.

McGonagle, J.J. \& Vella, C.M. 2002. A case for Competitive Intelligence: $90 \%$ of the information a company needs to understand its market and competitors and to make key decisions is already public. Information Management Journal, 36(4): 35-40.

Pellissier, R. \& Kruger, 2011. Understanding the use of strategic intelligence as a strategic management tool in the long-term insurance industry in South Africa. South African Journal of Information Management, 13(1). [Online]. Available: www.sajim.co.za. [Accessed 14 January 2012].

Prescot, J.E. 1999. The evolution of competitive intelligence - designing a process for action. Proposal Management, Spring: 37-52.

Schwab, K. (ed). 2013. Global competitiveness report 2013-2014. Geneva: World Economic Forum. http://www3.weforum.org/docs/WEF_GlobalCompetitivenessReport_2013-14.pdf pp 347 [Accessed: 5 May 2014].

Sewdass, N. 2009. The implementation of competitive intelligence tools and techniques in public service departments in South Africa to improve service delivery: A case study of the Department of Home Affairs. DPhil thesis. Department of Information Science, University of Pretoria, Pretoria.

Sewdass, N. (2012). Proposing a competitive intelligence (CI) framework for public service departments to enhance service delivery, South African Journal of Information Management, 14(1). [Online]. Available: www.sajim.co.za. [Accessed 10 June 2012].

Sewdass, N. \& Du Toit, A.S.A. 2014. Current state of competitive intelligence in South Africa. International Journal of Information Management, 34(2): 185-190.

Sewlal, R. 2004. Effectiveness of the Web as a competitive intelligence tool. South African Journal of Information Management, 6(1). [Online]. Available: www.sajim.co.za. [Accessed 10 December 2013]. 
Strauss, A.C. 2008.Competitive intelligence skills needed in South Africa. MCom dissertation. Johannesburg: University of Johannesburg.

Strauss, A.C. \& Du Toit, A.S.A. 2010. Competitive intelligence skills needed to enhance South Africa's competitiveness. Aslib Proceedings, 62(3): 302-320.

Viviers, W. \& Muller, M-L. 2004. The evolution of competitive intelligence in South Africa: Early 1980s - 2003. Journal of Competitive Intelligence and Management, 2(2): 53-67.

Viviers, W., Saayman, A., Calof, J.L. \& Muller, M-L. 2002. Competitive intelligence practices: A South African study. South African Journal of Business Management, 33(3: 27-37.

Waheeduzzaman, A.N.M. 2002. Competitiveness, human development and inequality: A cross-national comparative inquiry. Competitiveness Review, 12(2): 13-17.

Walle, A.H. 1999. From marketing research to competitive intelligence: Useful generalization or loss of focus? Management Decision, 37(6): 519-525.

Walliman, N.S.R. 2005. Your research project: A step-by-step guide for the first-time researcher. $2^{\text {nd }}$ ed. London: Sage

Zikmund, W.G. (2003). Business research methods. $7^{\text {th }}$ ed. Mason: South Western Thomson. 